\title{
Silymarin regulates HIF-1 $\alpha$ and iNOS expression in the brain and gills of hypoxic-reoxygenated rainbow trout Oncorhynchus mykiss
}

\author{
Hassan Malekinejad $^{1, *}$, Meysam Taheri-brujerdi ${ }^{1}$, Hamed Janbaz-Acyabar ${ }^{1}$, \\ Amir Amniattalab ${ }^{2}$
}

\footnotetext{
${ }^{1}$ Department of Pharmacology \& Toxicology, Faculty of Veterinary Medicine, PO Box 1177, Urmia University, Urmia, Iran ${ }^{2}$ Department of Pathology, Faculty of Veterinary Medicine, Urmia Branch, PO Box 969, Islamic Azad University, Urmia, Iran
}

\begin{abstract}
Rainbow trout Oncorhynchus mykiss were pre-treated with silymarin (SMN) to investigate its protective effects on hypoxia/reoxygenation (H/R)-induced pathological and oxidative impacts and on the expression of hypoxia-inducible factor $1 \alpha(\mathrm{HIF}-1 \alpha)$ and inducible nitric oxide synthase (iNOS) at the mRNA level in the brain and gills of trout. Fifty trout were assigned to control (normoxia) or treatment groups (H/R). The treatment trout were grouped into $H / R$, which received normal saline, and H/R+S 100, H/R+S 400 and H/R+S 800 treatments, which received 100, 400 and $800 \mathrm{mg}$ SMN, respectively, per $\mathrm{kg}$ of fish feed each day for $3 \mathrm{~d}$ prior to hypoxia. Hypoxia was induced by bubbling $\mathrm{N}_{2}$ gas into a water bath, resulting in a lower level of oxygen $\left(5 \mathrm{mg} \mathrm{l}^{-1}\right)$. Fish were kept in a hypoxic condition for $3 \mathrm{~h}$ followed by $3 \mathrm{~h}$ of normoxia (oxygen level at $10.4 \mathrm{mg} \mathrm{l}^{-1}$ ), and then blood and tissue were sampled. To evaluate the antioxidant status, the total antioxidant capacity (TAC), malondialdehyde (MDA) content, nitric oxide (NO) level and protein carbonylation rate were assessed in the brain and gills. The expression of HIF-1 $\alpha$ and iNOS mRNA was examined in the brain and gills using semi-quantitative RT-PCR. SMN lowered the H/R-elevated NO, MDA and carbonylated protein levels, while it enhanced the TAC level. Moreover, SMN regulated the H/R up-regulated level of HIF- $1 \alpha$ and iNOS in examined tissues. SMN ameliorated the H/Rinduced histopathological injuries in the brain and gills. These results suggest that pre-treatment of trout with SMN might be an applicable method for reducing H/R-induced biochemical, histopathological and transcriptional injuries.
\end{abstract}

KEY WORDS: Hypoxia $\cdot$ Oxidative status $\cdot$ Reoxygenation $\cdot$ Silymarin $\cdot$ Trout

Resale or republication not permitted without written consent of the publisher

\section{INTRODUCTION}

Aerobic animals, including fish, use oxygen for energy generation via oxidative phosphorylation, which is related to the reduction of oxygen to water by the cytochrome oxidase system (Kitazoe et al. 2011). Oxygen is a vital element in aquatic environments, but oxygen levels may vary widely and are influenced by water temperature, salinity, water flow, photosynthetic activities of algae and the intensity of respiration rates of organisms. Aquatic organisms, including fish, are exposed to different levels of oxy- gen daily and throughout different seasons. Another factor potentially causing hypoxia in cultured aquatic animals is extended shipping time in insufficiently oxygenated containers.

A large variation in tolerance to changes in oxygen level has been reported: cold-adapted fish, including rainbow trout, are sensitive to hypoxia, while cyprinid species can tolerate very low levels of oxygen (McKenzie et al. 2004, Lushchak \& Bagnyukova 2006a,b). During the last decade, it has been established that fish could be a novel model for investigating oxygen-level-mediating alterations. 
Hypoxia and subsequent reoxygenation resulted in a remarkable increase of oxidative stress biomarkers in tissues of the rotan Perccottus glenii and Leporinus elongatus (Filho et al. 2005, Lushchak et al. 2007). It has been generally accepted that the extra production of pro-oxidants, including reactive oxygen species (ROS) and reactive nitrogen species (RNS), may result in damage to cellular macromolecules, including proteins, lipids and DNA (Dröge 2002, Valko et al. 2007). Therefore, from a farming perspective and particularly in aquatic environments with high variation in oxygen level, the $\mathrm{O}_{2}$ utilization, ROS generation and antioxidant status are of great importance. To tolerate the various oxygen levels and to minimize hypoxia/reoxygenation (H/R)-induced oxidative injuries, fish species have developed several physiological adaptations, including metabolic rate depression, blood flow rearrangement mainly to the brain and heart and effective methods of energy production (Nilsson \& Renshaw 2004).

One of the known mediatory factors in hypoxic animals is the hypoxia-inducible factor $1 \alpha$ (HIF-1 $\alpha$ ), which is a key transcription factor in mediating different responses of animals and cells to hypoxia (Nikinmaa \& Rees 2005). For instance, the crucial role of HIF-1 $\alpha$ in hypoxia-induced changes in the gills of crucian carp has been reported. Another oxygen-dependent protein that is induced by HIF-1 $\alpha$ is inducible nitric oxide synthase (iNOS) (Palmer et al. 1998). Hypoxia-induced iNOS activity may result in an excessive production of $\mathrm{NO}$ and peroxynitrite $\left(\mathrm{ONOO}^{-}\right)$, which is highly reactive against biomolecules (Curtin et al. 2002).

Hypoxic/reoxygenated animals have developed physiological pathways to minimize injuries. Nevertheless, we hypothesized that implementing alternative and supportive approaches, such as pretreatment with antioxidants, may reduce H/R-induced injuries, especially in aquatic animals, which are frequently exposed to oxygen stress. Previous reports have indicated that the brain and gills are the most susceptible tissues to hypoxia (Olson 2008, Li et al. 2011); therefore, in the present study, these tissues were selected for investigation. Silymarin (SMN) is used as an effective hepatoprotective agent due to its antioxidant, anticancer and anti-inflammatory properties in humans and animals. Its immune stimulating effect has also been reported in rodents (Meeran et al. 2006). To examine our hypothesis, we investigated the protective effect of pretreatment with SMN on H/R-induced oxidative stress, histopathological damage, and the expression of HIF-1 $\alpha$ and iNOS mRNA in the brain and gills, of fingerling rainbow trout.

\section{MATERIALS AND METHODS}

\section{Chemicals}

SMN (S 0292) and 5.5'-dithiobis-2-nitrobenzoic acid (DTNB) were purchased from Sigma. Sulfanilamide and N-(1-naphthyl) ethylenediamine dihydrochloride were obtained from Sigma-Aldrich. Thiobarbituric acid, phosphoric acid (85\%), dimethyl sulfoxide (DMSO), sodium nitrite and ethanol were purchased from Merck. N-butanol was obtained from Carl Roth. TRI reagent was purchased from Applied Biosystems. All other chemicals were analytical grade commercial products.

\section{Animals}

Fifty fingerling rainbow trout (average weight $40 \pm$ $5 \mathrm{~g}$ ) were obtained from a local trout farm and transported to the Artemia and Aquatic Animals Research Institute (Urmia, Iran) in an oxygenated tank. They were then stocked in a concrete pond containing underground freshwater. The fish were cultured in a flow-through system with a flow rate of $501 \mathrm{~min}^{-1}$. Dissolved oxygen was maintained above $8 \mathrm{mg} \mathrm{l}^{-1}$ using constant aeration and fish were exposed to a natural photoperiod of approximately $12 \mathrm{~h}$ light: $12 \mathrm{~h}$ dark. Water temperature was $13.5 \pm 1^{\circ} \mathrm{C}$, and $\mathrm{pH} 7.30$ to 7.50 . The fish were fed a standard commercial mycotoxin-free formulated trout diet (Milade-Mahabad) throughout the adaptation and experimentation periods.

\section{Experimental design}

Fish were randomly assigned to control (normoxia, $\mathrm{n}=10$ ) or treatment groups (H/R). All of the treatment groups ( $\mathrm{n}=10$ ) were subjected to H/R and classified according to the concentration of SMN that had been added to their diet. The treatment groups included $H / R$, which received only saline and the solvent of the test compound $(<5 \%$ of the final volume), and SMN 100, SMN 400 and SMN 800, which received 100, 400 and $800 \mathrm{mg}$ SMN, respectively, per $\mathrm{kg}$ of fish feed each day for $3 \mathrm{~d}$ prior to exposure to H/R. All procedures were approved by the local ethical committee in accordance with principles of laboratory animal care.

\section{Hypoxia and reoxygenation}

Fish in the H/R and treatment groups were exposed to H/R following $3 \mathrm{~d}$ of pre-treatment with 
normal saline and/or various concentrations of SMN. Hypoxia was induced by the administration of $\mathrm{N}_{2}$ gas directly into the bath, lowering the oxygen level to $5 \mathrm{mg} \mathrm{l}^{-1}$ over $20 \mathrm{~min}$. The oxygen level was monitored throughout the experiment using an oxygen meter (YSI 55). The fish remained in a hypoxic condition for $3 \mathrm{~h}$. The fish were then transferred to normoxic (oxygen level of $10.4 \mathrm{mg} \mathrm{l}^{-1}$ ) conditions for $3 \mathrm{~h}$ and then were subjected to blood and tissue sampling. The $5 \mathrm{mg} \mathrm{l}^{-1}$ oxygen level was selected after testing various oxygen levels of 3,4 and $5 \mathrm{mg} \mathrm{l}^{-1}$; the fingerling trout tolerated $5 \mathrm{mg} \mathrm{l}^{-1}$ oxygen for $3 \mathrm{~h}$.

\section{Blood and tissue sampling}

For blood and tissue collection, the fish were anesthetized by immersion in eugenol solution $\left(20 \mathrm{mg} \mathrm{l}^{-1}\right)$, and immediately, blood samples were collected from anesthetized trout by puncturing the caudal vein. The blood samples were subjected to serum preparation by centrifugation at $3000 \times g$ for $5 \mathrm{~min}$, and the collected serum samples were stored at $-20^{\circ} \mathrm{C}$ for further biochemical analyses. After blood sampling, the fish were dissected to remove the brain and gills. The collected tissue samples were rinsed 3 times with chilled normal saline to remove excess blood and immediately divided into 2 parts. The first part was snap-frozen in liquid nitrogen and stored at $-80^{\circ} \mathrm{C}$ for further molecular analyses, and the second half was kept in $10 \%$ formalin for further histopathological examinations.

\section{Alanine aminotransaminase (ALT) serum level}

The serum level of ALT was measured using a commercially available standard kit according to the manufacturer's instructions (10-513, Zist Shimi).

\section{Antioxidant status}

To evaluate the antioxidant status in the H/R-exposed animals and to determine the protective effect of SMN on H/R-induced alterations in antioxidant status, several biomarkers were assessed.

\section{Total antioxidant capacity (TAC) assay}

The total antioxidant capacity of serum was measured in all experimental groups. The assay is based on an assessment of the ferric reduction antioxidant power (FRAP) (Benzie \& Strain 1999). Briefly, at low $\mathrm{pH}$, which was achieved by the addition of acetate buffer (300 mM, pH 3.6), reduction of the Fe(III)-TPTZ complex to the ferrous form produces an intensive blue color that can be measured at $593 \mathrm{~nm}$. An aqueous solution of $\mathrm{Fe}(\mathrm{II})\left(\mathrm{FeSO}_{4} \cdot 7 \mathrm{H}_{2} \mathrm{O}\right)$ and appropriate concentrations of freshly prepared ascorbic acid were used as blank and standard solutions, respectively.

\section{Malondialdehyde (MDA) determination}

To determine the lipid peroxidation rate in the control and test groups, the MDA content of the brain and gill samples was measured using the thiobarbituric acid (TBA) reaction as described by Niehaus et al. (1968). Briefly, 0.2 to $0.3 \mathrm{~g}$ of the samples were homogenized in ice-cooled $\mathrm{KCl}(150 \mathrm{mM})$, and the mixture was centrifuged at $3000 \times g$ for $10 \mathrm{~min} ; 0.5 \mathrm{ml}$ of the supernatant was mixed with $3 \mathrm{ml}$ of phosphoric acid $(1 \% \mathrm{~V} / \mathrm{V})$, and after vortex mixing, $1 \mathrm{ml}$ of $6.7 \mathrm{~g}$ $\mathrm{l}^{-1}$ TBA was added to the samples. The samples were heated at $100^{\circ} \mathrm{C}$ for $45 \mathrm{~min}$ and then chilled in ice. After an addition of $3 \mathrm{ml}$ of $\mathrm{N}$-butanol, the samples were centrifuged at $3000 \times g$ for $10 \mathrm{~min}$. The absorbance of the supernatant was measured spectrophotometrically (Pharmacia Novaspec II, Biochrom) at $532 \mathrm{~nm}$, and the MDA level was calculated according to the simultaneously prepared calibration curve using MDA standards. The amount of MDA was expressed as nmol per mg of protein. The protein content of the samples was assessed following Lowry et al. (1951).

\section{NO measurement}

The total NO content of the brain and gill tissue was measured according to the Griess reaction (Green et al. 1982). In the Griess reaction, NO is rapidly converted into the more stable nitrite, and in an acidic environment, nitrite is converted to $\mathrm{HNO}_{2}$. In reaction with sulfanilamide, $\mathrm{HNO}_{2}$ forms a diazonium salt, which reacts with $\mathrm{N}$-(1-naphthyl) ethylenediamine dihydrochloride to form an azo dye that can be detected by absorbance at a wavelength of $540 \mathrm{~nm}$. The NO content of the examined organs was expressed as nmol per $\mathrm{mg}$ of protein in samples.

\section{Protein carbonylation assay}

To determine the carbonyl content of the tissue homogenates (brain and gills), the reaction between 2,4-dinitrophenylhydrazine (DNPH) and protein carbonyls was measured (Levine et al. 1994). Briefly, 0.2 to $0.3 \mathrm{~g}$ of the samples were homogenized in icecooled phosphate buffer $(50 \mathrm{mM}, \mathrm{pH}$ 6.7, with $1 \mathrm{mM}$ EDTA), and the mixture was centrifuged at $10000 \times g$ 
for $10 \mathrm{~min}$ at $4^{\circ} \mathrm{C}$. For each individual sample $(0.2 \mathrm{ml}$ supernatant), a test and a control sample were prepared, and $0.8 \mathrm{ml}$ of $\mathrm{DNPH}$ and $2 \mathrm{M} \mathrm{HCl}$ solutions were added to the test and control samples, respectively. The samples were kept in the dark at room temperature for $1 \mathrm{~h}$, with vortex mixing every $15 \mathrm{~min}$. After 1 h, $0.5 \mathrm{ml}$ trichloroacetic acid $30 \%$ were added in each sample and vortex mixed for $30 \mathrm{~s}$. All samples were centrifuged at $10000 \times g$ for $3 \mathrm{~min}$, the supernatant was discarded, and the precipitate re-suspended for $15 \mathrm{~min}$ in $1 \mathrm{ml}$ of (1:1) ethanol/ethyl acetate solution. After centrifugation at $10000 \times g$ for $3 \mathrm{~min}$ and discarding the supernatant, the above step was repeated. Following the last wash, the precipitates were dissolved within $0.6 \mathrm{ml}$ guanidine hydrochloride solution $(6 \mathrm{M})$ at $37^{\circ} \mathrm{C}$ for $15 \mathrm{~min}$. After dissolving the precipitate, the samples were centrifuged at $10000 \times g$ for $3 \mathrm{~min}$, to remove any leftover debris. For each sample, the optical density (OD) was measured against a $6 \mathrm{M}$ guanidine hydrochloride solution at a wavelength of $370 \mathrm{~nm}$.

The carbonyl content was determined as follows:

$$
\begin{gathered}
\text { Carbonyl }\left(\mathrm{nmol} \mathrm{ml}{ }^{-1}\right)= \\
{\left[\left(\mathrm{CA} / 0.011 \mathrm{mM}^{-1}\right)\right](600 \mu \mathrm{l} / 200 \mu \mathrm{l})}
\end{gathered}
$$

where CA, which is the corrected absorbance and computed as the average OD for each control sample, was subtracted from the average OD of the test sample at $370 \mathrm{~nm}$. The extinction coefficient for $\mathrm{DNPH}$ at $370 \mathrm{~nm}$ is $22000 \mathrm{M}^{-1} \mathrm{~cm}^{-1}$. To determine the carbonyl content per mg of protein, the protein levels were measured at $280 \mathrm{~nm}$ in each sample. The amount of protein was calculated from a bovine serum albumin (BSA) standard curve $(0.25$ to $2.0 \mathrm{mg}$ $\mathrm{ml}^{-1}$ ) that was dissolved in guanidine hydrochloride.

\section{Histopathological examinations}

Tissue samples from the brain and gill tissues, which had previously been stored in $10 \%$ buffered formaldehyde, were embedded in paraffin, and 5 to $6 \mu \mathrm{m}$ sections were cut using a rotary microtome and stained with hematoxylin and eosin. To evaluate the level of damage following exposure to H/R and the protective effect of SMN, indices including vasogenic edema, local congestion, increase of meninges thickness and chromatolysis in Purkinje cells of cerebral tissue, hyperplasia of epithelial and pillar cells, adherence between secondary lamellae and necrosis of the lamellae of the gills were scored numerically. The evaluation criteria were as follows: 0 for no detectable lesion, 1 for mild, 2 for moderate and 3 for severe changes. The pathologist who examined the sections was unaware of the experimental details. For each animal in the test and control groups, at least 3 slides from distinct organs were prepared and scored. The numerical data are presented as the sum of the score of 3 slides for each individual fish, and the deviation among the individuals of each experimental group was computed.

\section{RNA isolation and RT-PCR}

To evaluate the effect of H/R and SMN pretreatment on the mRNA level of HIF-1 $\alpha$ and iNOS in the brain and gill tissues, total RNA was isolated from pooled sample homogenates for the control and test groups $(\mathrm{n}=10)$ using the standard TRIZOL method (Chomczynski \& Sacchi 2006). To avoid genomic DNA contamination, extra care was taken when the colorless aqueous phase was collected after chloroform extraction. The RNA amount was determined spectrophotometrically (260 $\mathrm{nm}$ and A260/280 = 1.8 to 2.0), and the samples were stored at $-70^{\circ} \mathrm{C}$. For RT-PCR, cDNA was synthesized in a $20 \mu$ reaction mixture containing $1 \mu \mathrm{g}$ RNA, oligo(dT) primer $(1 \mu \mathrm{l})$, 5 reaction buffer $(4 \mu \mathrm{l})$, RNAse inhibitor $(1 \mu \mathrm{l}), 10 \mathrm{mM}$ dNTP mix $(2 \mu l)$ and M-MuLV Reverse Transcriptase $(1 \mu \mathrm{l})$ according to the manufacturer's protocol (Fermentas). The cycling protocol for $20 \mu \mathrm{l}$ reaction mix was $5 \mathrm{~min}$ at $65^{\circ} \mathrm{C}$, followed by $60 \mathrm{~min}$ at $42^{\circ} \mathrm{C}$ and $5 \mathrm{~min}$ at $70^{\circ} \mathrm{C}$ to terminate the reaction.

\section{Second strand cDNA synthesis}

The reaction was carried out in a total volume of $25 \mu \mathrm{l}$ containing PCR master mix $(12.5 \mu \mathrm{l})$, gene specific primers $(0.5 \mu \mathrm{l}$ each) and cDNA as template $(1 \mu \mathrm{l})$ and nuclease-free water $(10.5 \mu \mathrm{l})$. PCR conditions were run as follows: general denaturation at $95^{\circ} \mathrm{C}$ for $3 \mathrm{~min}$ in 1 cycle, followed by 40 cycles of $95^{\circ} \mathrm{C}$ for $20 \mathrm{~s}$, an annealing temperature $\left(61^{\circ} \mathrm{C}\right.$ for $\mathrm{HIF}-1 \alpha, 65^{\circ} \mathrm{C}$ for iNOS, and $60^{\circ} \mathrm{C}$ for glyceraldehyde3 -phosphate dehydrogenase [GAPDH]) for $30 \mathrm{~s}$ and elongation at $72^{\circ} \mathrm{C}$ for $1 \mathrm{~min}$, and terminating with $72^{\circ} \mathrm{C}$ for $5 \mathrm{~min}$. The PCR products were separated on $1.5 \%$ agarose gels containing ethidium bromide and visualized using the Gel Doc 2000 system (Bio-Rad). The density of the RT-PCR bands was quantified using the Molecular Analyst software (Bio-Rad) and normalized based on the density of corresponding GAPDH bands. The RT-PCR reaction and subsequent electrophoresis were performed 3 times, and 
Table 1. Primer pairs used for PCR. FWD: Forward, REV: Reverse, GAPDH: glyceraldehyde 3-phosphate dehydrogenase, HIF-1 $\alpha$ : hypoxia-inducible factor $1 \alpha$, iNOS: inducible nitric oxide synthase

\begin{tabular}{|lccccc|}
\hline Name & Gene & $\begin{array}{c}\text { PCR product } \\
\text { size }(\mathrm{bp})\end{array}$ & $\begin{array}{c}\text { Annealing } \\
\text { temperature }\left({ }^{\circ} \mathrm{C}\right)\end{array}$ & Sequence (5' to 3') \\
\hline $\begin{array}{l}\text { GAPDH FWD } \\
\text { GAPDH REV }\end{array}$ & GAPDH & 556 & 60 & ATG TCA GAC CTC TGT GTT GG \\
HIF-1 $\alpha$ FWD & GIF-1 $\alpha$ & 378 & 61 & TCC TCG ATG CCG AAG TTG TCG \\
$\begin{array}{l}\text { HIF-1 } \alpha \text { REV } \\
\text { iNOS FWD }\end{array}$ & HIF-1 $\alpha$ & 469 & 65 & GAC TCA GGC CAC TGT TAT CTA CAA \\
iNOS REV & iNOS & & & GTG CGT AAC GTG AAG GAT GGC TC \\
\end{tabular}

the averages of numerical densitometric values along with standard deviation were calculated.

The specific primers for rainbow trout GAPDH (Collet et al. 2003), HIF-1 $\alpha$ (GenBank AF304864) and iNOS (Wang et al. 2001) were designed and manufactured by CinnaGen. The primer pairs used and expected size of PCR products are depicted in Table 1.

\section{Statistical analysis}

The means and standard deviations of the measured parameters were calculated. The results of 3 independent experiments for each assessment were analyzed using GraphPad Prism software (version 2.01). The comparisons between groups were made by ANOVA followed by Bonferroni post-hoc tests. For comparing the graded degree of pathological findings between groups, the Kruskal-Wallis test was used. $\mathrm{p}<0.05$ was considered significant.

\section{RESULTS}

\section{SMN antioxident and anti-inflammatory effects}

Exposure to H/R resulted in a significant $(p<0.01)$ decline of TAC compared to the control group, while pre-treatment with SMN at various dose levels increased the TAC significantly $(p<0.05)$. Although SMN treatment at 100 and $400 \mathrm{mg} \mathrm{kg}^{-1}$ could recover the H/R-reduced TAC, at the $800 \mathrm{mg} \mathrm{kg}^{-1}$ dose, the effect of SMN was not significant (Table 2). The hepatic functional enzyme level in serum was measured in various study groups, and the results revealed that $3 \mathrm{~h}$ hypoxia followed with $3 \mathrm{~h}$ of reoxygenation resulted in a significant elevation of the serum level of ALT. The pretreatment with SMN at 100 and $400 \mathrm{mg} \mathrm{kg}^{-1}$ but not at $800 \mathrm{mg} \mathrm{kg}^{-1}$ resulted in a remarkable decline of the ALT serum level (Table 2).

To analyze the antioxidant status following exposure to H/R in trout, the rates of protein oxidation and lipid peroxidation and the NO content of brain and gills were measured. The results showed that all 3 factors were elevated significantly $(p<0.01)$ in the brain and gills of the H/R group. The $3 \mathrm{~d}$ pretreatment with various concentrations of SMN resulted in a significant and concentration-dependent reduction of the H/R-elevated NO content, MDA level and rate of protein carbonylation in the brain (Fig. $1 \mathrm{~A}, \mathrm{~B}, \mathrm{C}$ ). SMN was able to reduce the H/R-elevated levels of NO, MDA and carbonylated protein content in the gills of trout. However, the antioxidant effects of SMN in the gills were not concentration dependent; the maximum reduction of the pro-oxidant levels was obtained at $400 \mathrm{mg} \mathrm{kg}^{-1}$ of fish feed (Fig. 1D,E,F).

\section{Pathological findings}

The histopathological examination of the brain and gills in the control group showed no remarkable pathologic changes (Fig. 2A \& 3A). In contrast, trout that were exposed to H/R showed local congestion,

Table 2. Oncorhynchus mykiss. Effect (mean $\pm \mathrm{SD}$ ) of pretreatment of trout with 3 levels of silymarin (SMN) on total antioxidant capacity (TAC) and serum level of alanine aminotransaminase (ALT) in experimental groups. Different letters signify statistically distinct groups $(p<0.05)$. H/R: hypoxia/reoxygenation

\begin{tabular}{|lcc|}
\hline Groups & TAC $\left.(\mu \mathrm{mol} \mathrm{l})^{-1}\right)$ & ALT $\left(\mathrm{U} \mathrm{l}^{-1}\right)$ \\
\hline Control & $0.83 \pm 0.06^{\mathrm{a}}$ & $71.7 \pm 18.9^{\mathrm{a}}$ \\
H/R & $0.54 \pm 0.03^{\mathrm{b}}$ & $160.3 \pm 12.8^{\mathrm{b}}$ \\
H/R+S100 & $0.77 \pm 0.02^{\mathrm{c}}$ & $96.9 \pm 7.2^{\mathrm{c}}$ \\
H/R+S400 & $0.90 \pm 0.06^{\mathrm{c}, \mathrm{d}}$ & $57.5 \pm 14.3^{\mathrm{c}, \mathrm{d}}$ \\
H/R+S800 & $0.60 \pm 0.04^{\mathrm{d}}$ & $127.0 \pm 23.5^{\mathrm{d}}$ \\
\hline
\end{tabular}



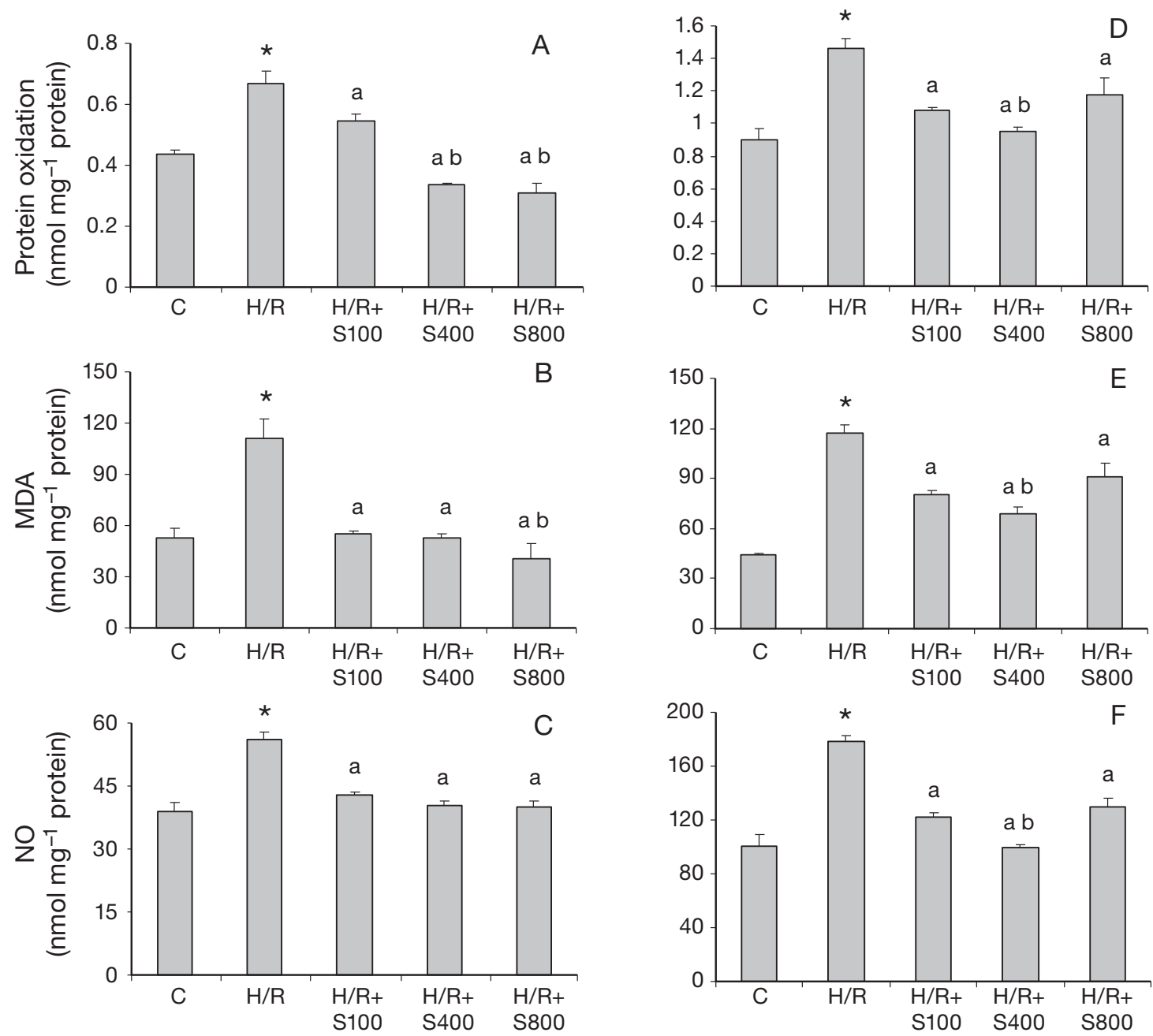

Fig. 1. Oncorhynchus mykiss. Diagrams showing the protective effect of silymarin (SMN) on hypoxia/reoxygenation (H/R)induced oxidative impact in the brain (left) and gills (right) of trout, expressed as levels of protein oxidation, melondialdehyde (MDA) and nitric oxide (NO). H/R: trout exposed to 3 h hypoxia followed by 3 h reoxygenation; H/R+S100, +S400, +S800: animals pretreated with $100,400,800 \mathrm{mg} \mathrm{kg}^{-1} \mathrm{SMN}$ before H/R, respectively. ${ }^{*}$ Significant $(\mathrm{p}<0.01)$ increase of all 3 oxidative stress biomarkers in the H/R group compared to the control group. Different lowercase letters represent significant differences among the SMN-treated groups themselves and the H/R group

increase of meningeal thickness and focal aggregation of glial cells (gliosis) in the cerebrum (Fig. 2B). In the same animals, the gills showed hyperplasia of epithelial and pillar cells in secondary lamellae and destruction of superficial cells (Fig. 3B). Interestingly, pre-treatment with SMN reduced the H/R-induced lesions in the brain in a concentration-dependent fashion, as at the highest given concentration, no pathological signs were observed (Fig. 2C,D,E). We found that SMN could strongly protect the gills from H/R-induced damages, but at the highest given concentration (800 mg kg${ }^{-1}$ feed), severe pathological injuries, such as necrosis of lamellae, were demonstrated (Fig. 3C,D,E). The histopathological lesions are depicted as scored numerical data in Table 3.

\section{SMN regulatory effect on HIF-1 $\alpha$ and iNOS expression}

The expression of HIF- $1 \alpha$ and iNOS in the brain and gills at mRNA level was examined through densitometric analyses for both genes in the examined tissues after normalization to the corresponding GAPDH bands, and the results indicate that although HIF-1 $\alpha$ was expressed in the brain of intact trout, iNOS expression was not detectable. Both genes were expressed in the gills of the control trout. Both genes were up-regulated following exposure to hypoxia and reoxygenation in the brain and gills (Fig. 4A,B). The pretreatment with SMN regulated the expression of HIF-1 $\alpha$ in a dose-dependent man- 

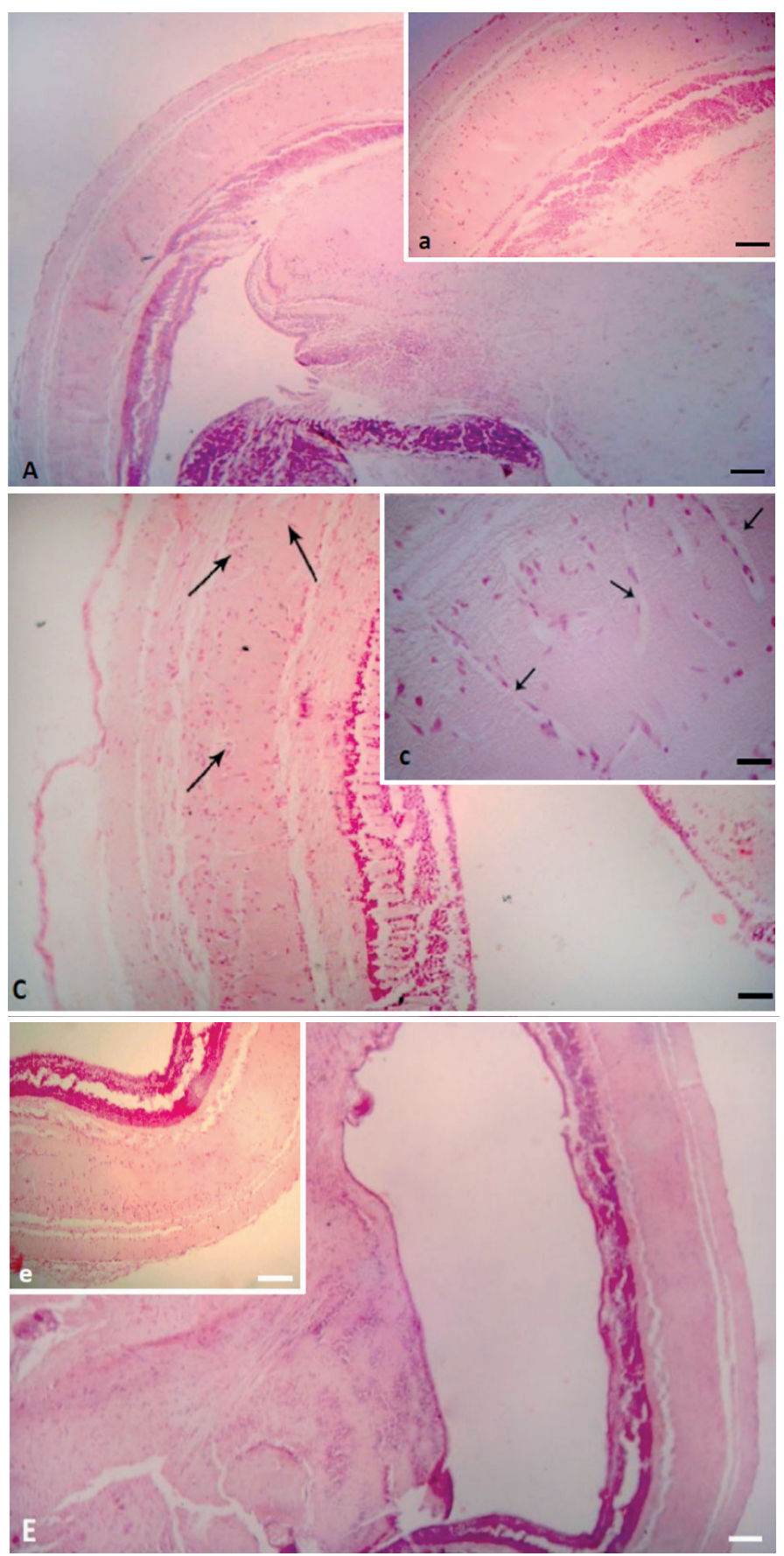

ner in the brain but not in the gills. SMN at $800 \mathrm{mg}$ $\mathrm{kg}^{-1}$ did not regulate the H/R-induced expression of HIF-1 $\alpha$ in the gills. The iNOS expression in the brain of all SMN-pretreated groups was completely silenced, while in the gills, the H/R-induced iNOS expression was down-regulated at the studied doses. The down-regulation of iNOS in the SMN-pretreated groups was not dose-dependent (Fig. 4C,D).
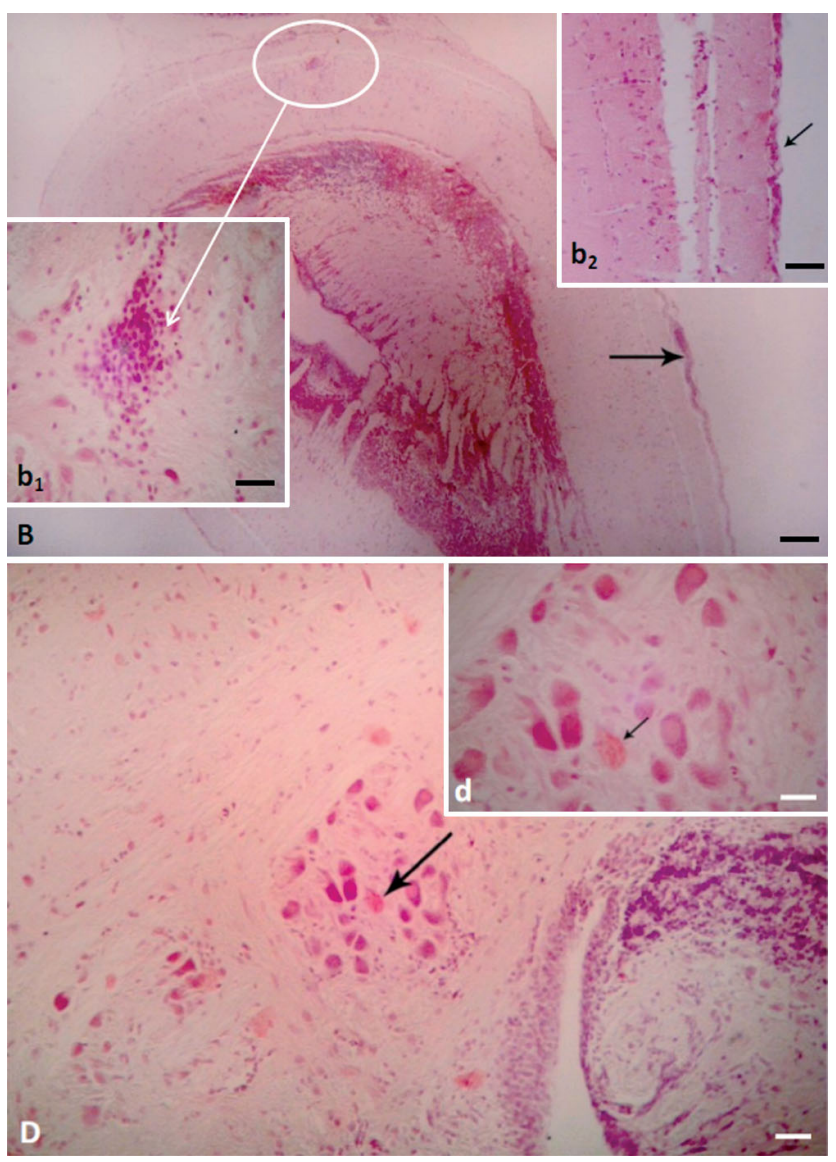

Fig. 2. Oncorhynchus mykiss. Photomicrograph of trout brain: (A) normal appearance of trout tissue, (a) shows the cerebral tissue with high magnification; (B) focal aggregation of glial cells (arrows) ( $\mathrm{b}_{1}$ : gliosis is presented with high magnification) and $\left(b_{2}\right)$ the local congestion and increase of meningeal thickness in the cerebrum with hypoxia/ reoxygenation (H/R)-induced pathological damages; (C) vasogenic edema in the cerebral tissue and creation of white spaces around vessels (arrows) (c: higher magnification) found in the trout that received $100 \mathrm{mg} \mathrm{kg}^{-1} \mathrm{SMN}_{i}(\mathrm{D})$ chromatolysis in Purkinje cells of the cerebral tissue (arrows) (d: high magnification) in trout pretreated with $400 \mathrm{mg} \mathrm{kg}^{-1}$ SMN before $H / R_{i}$ (E) cerebral tissue from trout pretreated with $800 \mathrm{mg} \mathrm{kg}^{-1} \mathrm{SMN}$ before H/R, in which no pathological sign was observed. $(A, B, C, E) 100 \times$ magnification, $\left(D, a, b_{1}, C, e\right)$ $400 \times$ magnification, $\left(\mathrm{b}_{2}\right) 600 \times$ magnification, (d) $800 \times$ magnification. Scale bar $=100 \mu \mathrm{m}(\mathrm{A}, \mathrm{B}, \mathrm{C}, \mathrm{E}), 25 \mu \mathrm{m}\left(\mathrm{D}, \mathrm{a}, \mathrm{b}_{1}, \mathrm{ce}\right)$, $20 \mu \mathrm{m}\left(\mathrm{b}_{2}\right)$ or $10 \mu \mathrm{m}(\mathrm{d})$. H\&E staining

\section{DISCUSSION}

The present study showed that pretreatment with SMN was able to reduce the H/R-induced oxidative/nitrosative stress in the brain and gills of trout. The up-regulated mRNA levels of HIF-1 $\alpha$ and iNOS were also a result of the SMN pretreatment.

Experimentally produced or environmentally occurring hypoxia may cause various damage to differ- 

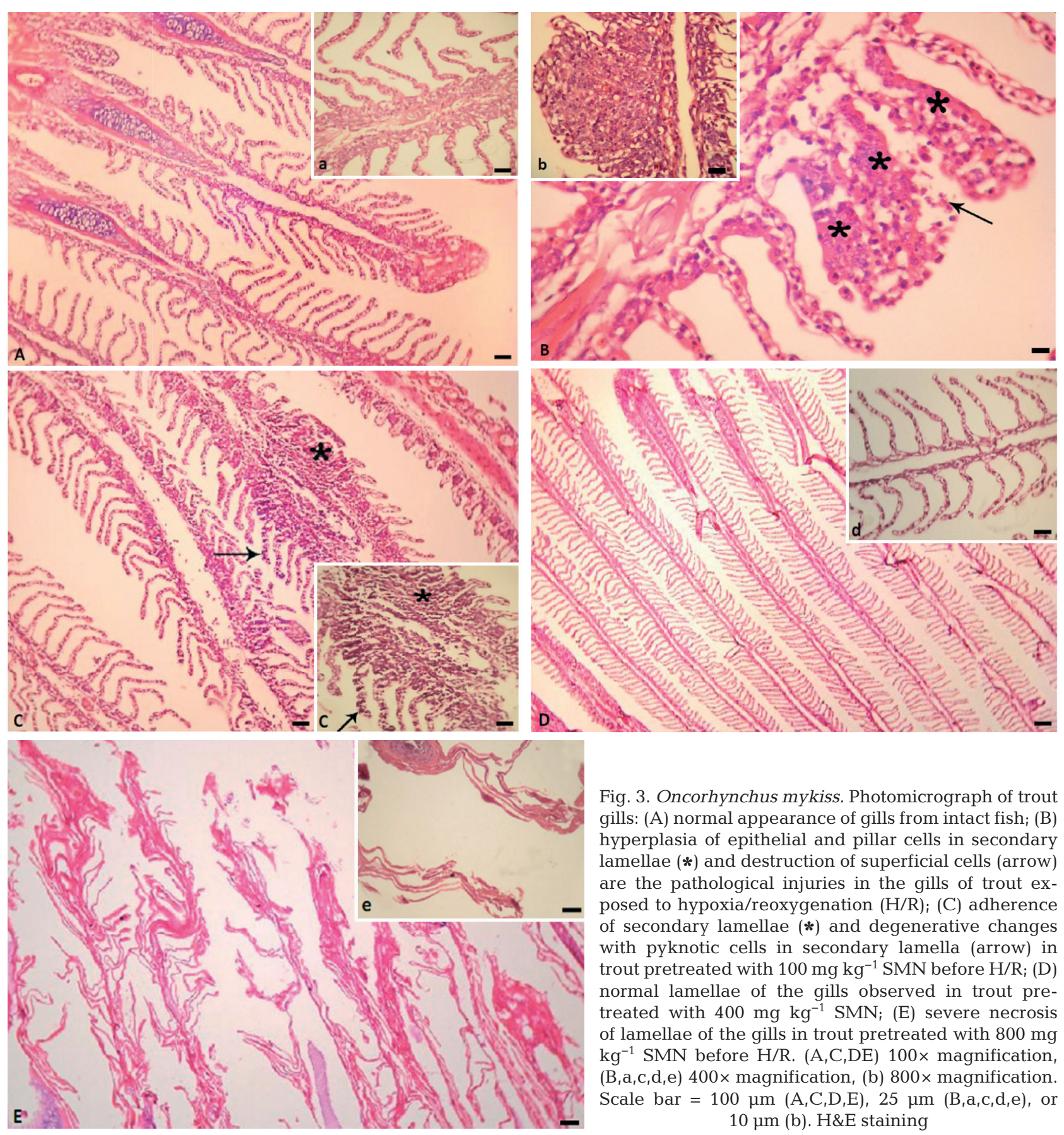

Fig. 3. Oncorhynchus mykiss. Photomicrograph of trout gills: (A) normal appearance of gills from intact fish; (B) hyperplasia of epithelial and pillar cells in secondary lamellae (*) and destruction of superficial cells (arrow) are the pathological injuries in the gills of trout exposed to hypoxia/reoxygenation (H/R); (C) adherence of secondary lamellae $(*)$ and degenerative changes with pyknotic cells in secondary lamella (arrow) in trout pretreated with $100 \mathrm{mg} \mathrm{kg}^{-1}$ SMN before H/R (D) normal lamellae of the gills observed in trout pretreated with $400 \mathrm{mg} \mathrm{kg}^{-1} \mathrm{SMN}_{\text {; }}$ (E) severe necrosis of lamellae of the gills in trout pretreated with $800 \mathrm{mg}$ $\mathrm{kg}^{-1} \mathrm{SMN}$ before H/R. (A,C,DE) 100× magnification, $(\mathrm{B}, \mathrm{a}, \mathrm{c}, \mathrm{d}, \mathrm{e}) 400 \times$ magnification, (b) 800× magnification. Scale bar $=100 \mu \mathrm{m}(\mathrm{A}, \mathrm{C}, \mathrm{D}, \mathrm{E}), 25 \mu \mathrm{m}(\mathrm{B}, \mathrm{a}, \mathrm{c}, \mathrm{d}, \mathrm{e})$, or $10 \mu \mathrm{m}(\mathrm{b})$. H\&E staining

ent organs. As a prerequisite of the present study, we established the tolerance level of hypoxia for fingerling trout at $5 \mathrm{ppm}$ oxygen for $3 \mathrm{~h}$ (data not shown). This finding is in accordance with previous studies which also reported $5 \mathrm{ppm}$ as the lowest level of oxygen that trout can tolerate (Piper et al. 1982).

To show the H/R-induced impact and to evaluate the potential protective effect of SMN, 2 tissues were selected, the brain and gills, because both tissues are the most sensitive and vulnerable organs to oxy- gen changes and oxidative stress-induced damages (Zhang et al. 2009). Also, it has been shown that the responses of fish to hypoxia are initiated by chemoreceptors, which are located in the first arch of the gills (Coolidge et al. 2008).

Generally, cultured trout are introduced to freshly prepared water with a high level of oxygen. There are increasing data indicating that reoxygenation itself may cause severe cellular and molecular injuries. As it is the excessive production of reactive 
Table 3. Oncorhynchus mykiss. Pathological findings (mean \pm SE) in the brain and gills of trout. Values in the same column with different superscripts differ significantly $(\mathrm{p}<0.05)$. H/R: trout exposed to $3 \mathrm{~h}$ hypoxia followed by $3 \mathrm{~h}$ reoxygenation; $\mathrm{H} / \mathrm{R}+\mathrm{S} 100,+\mathrm{S} 400,+\mathrm{S} 800$ : animals pretreated with 100,400 , $800 \mathrm{mg} \mathrm{kg}^{-1} \mathrm{SMN}$ before H/R, respectively

\begin{tabular}{|c|c|c|c|}
\hline \multirow{2}{*}{ Groups } & \multirow[b]{2}{*}{$\begin{array}{l}\text { Vasogenic } \\
\text { edema }\end{array}$} & \multirow{2}{*}{$\begin{array}{l}\text { Brain - } \\
\text { Chromatolysis }\end{array}$} & \multirow[b]{2}{*}{$\begin{array}{c}\text { Increase of meningeal } \\
\text { thickness }\end{array}$} \\
\hline & & & \\
\hline Control & $0.0^{\mathrm{a}}$ & $0.7 \pm 0.6^{\mathrm{a}}$ & $0.0^{\mathrm{a}}$ \\
\hline $\mathrm{H} / \mathrm{R}$ & $7.0 \pm 1.3^{b}$ & $5.0 \pm 0.7^{b}$ & $8.0 \pm 1.6^{b}$ \\
\hline $\mathrm{H} / \mathrm{R}+\mathrm{S} 100$ & $5.2 \pm 1.2^{\mathrm{b}}$ & $4.0 \pm 1.3^{b}$ & $3.6 \pm 0.3^{c}$ \\
\hline $\mathrm{H} / \mathrm{R}+\mathrm{S} 400$ & $4.0 \pm 1.5^{\mathrm{c}}$ & $4.0 \pm 0.3^{b}$ & $3.0 \pm 0.4^{b}$ \\
\hline \multirow[t]{2}{*}{$\mathrm{H} / \mathrm{R}+\mathrm{S} 800$} & $0.0^{\mathrm{d}}$ & $0.0^{\mathrm{c}}$ & $0.0^{\mathrm{c}}$ \\
\hline & $\begin{array}{l}\text { Hyperplasia in } \\
\text { epithelial cells }\end{array}$ & $\begin{array}{c}\text { Adherence of } \\
\text { secondary lamellae }\end{array}$ & $\begin{array}{c}\text { Pyknotic cells in } \\
\text { secondary lamellae }\end{array}$ \\
\hline Control & $0.0^{\mathrm{a}}$ & $0.0^{\mathrm{a}}$ & $0.0^{\mathrm{a}}$ \\
\hline $\mathrm{H} / \mathrm{R}$ & $8.0 \pm 1.7^{b}$ & $7.0 \pm 1.2^{b}$ & $6.0 \pm 1.8^{b}$ \\
\hline $\mathrm{H} / \mathrm{R}+\mathrm{S} 100$ & $5.0 \pm 0.9^{c}$ & $7.0 \pm 1.3^{b}$ & $4.0 \pm 1.3^{b}$ \\
\hline $\mathrm{H} / \mathrm{R}+\mathrm{S} 400$ & $1.0 \pm 0.3^{\mathrm{d}}$ & $1.0 \pm 0.6^{\mathrm{c}}$ & $0.0^{\mathrm{c}}$ \\
\hline $\mathrm{H} / \mathrm{R}+\mathrm{S} 800$ & $5.0 \pm 1.2^{\mathrm{c}}$ & $8.0 \pm 1.8^{b}$ & $6.0 \pm 0.9^{b}$ \\
\hline
\end{tabular}

The second part of the present study was performed to highlight any changes in the mRNA levels of the HIF- $1 \alpha$ and iNOS genes in the H/Rexposed trout. Although the expression of the 2 genes varied between the studied organs in normoxic trout, the exposure of fingerling trout to $3 \mathrm{~h}$ of hypoxia and $3 \mathrm{~h}$ of reoxygenation resulted in remarkable up-regulation of both genes in both organs. It has been shown in previous studies that the main transcriptional regulator of hypoxia is HIF-1 $\alpha$, and in normoxic situations, an oxygen-dependent hydroxylation of proline residues stimulates protein degradation and ultimately inhibits the accumulation of HIF-1 $\alpha$ (Ivan et al. 2001). Our findings support the previous in vitro studies as the HIF-1 $\alpha$ protein accumulated in trout hepatocytes that were exposed

oxygen species (ROS) and reactive nitrogen species (RNS) that play a key role in H/R-induced damages (Chuanyu \& Jackson 2002), it was necessary to identify any changes in the antioxidant status of trout that were exposed to H/R. Indeed, our results for the H/R group showed a significant increase in ROS and RNS production and consequently ROS/RNS-induced damages, which were characterized by lipid and protein peroxidation or by a reduction in TAC. The reduction in TAC was later confirmed by a remarkable increase in the NO content of brain and gills. These findings confirmed previous reports that H/R results in oxidative stress and demonstrated that in H/R-induced injuries, NO production may also play a key role in lipid and protein oxidation in trout.

There are reports indicating that NO formation from nitrite is elevated in mammals during hypoxia (Lundgreen et al. 2008). Once the NO production due to hypoxia is elevated and the hypoxia is followed by reoxygenation, the extra NO will rapidly react with $\mathrm{O}_{2}$ and yield the potent oxidant peroxynitrite anion $\left(\mathrm{ONOO}^{-}\right)$, which can ultimately act as an $\mathrm{OH}$ free radical (Beckman et al. 1990). Therefore, the elevated NO content in the examined tissues of the trout exposed to H/R may contribute to the reduction in TAC and the marked enhancement of lipid peroxidation and protein oxidation. In a rodent model, it has been shown that a high concentration of NO inhibits the cellular respiratory chain complexes, probably by nitrosylation and oxidation of protein thiol (Brown 1999). to oxygen stress, and the highest amount of protein was measured $2 \mathrm{~h}$ after hypoxia. The accumulation of HIF-1 $\alpha$ protein was explained by up-regulation of oxygen-sensitive prolyl hydroxylases during hypoxia (Stroka et al. 2001, Aprelikova et al. 2004, Rissanen et al. 2006).

The present study showed that in addition to HIF$1 \alpha$, iNOS was also up-regulated in the examined tissues under the H/R conditions. There are reports indicating that iNOS is another oxygen-dependent gene that is regulated by the HIF-1 $\alpha$ transcription factor during hypoxia; however, in the present study, we did not study the iNOS regulation through HIF-1 $\alpha$ in the H/R exposed trout. It seems there should be a strong relationship between the H/Rinduced up-regulation of HIF-1 $\alpha$ and the iNOS expression, which was mediated by the elevation of NO production in the examined organs. In agreement with our hypothesized pathway in the H/Rexposed trout, there are supporting reports indicating biphasic relationships among hypoxia, NO concentration and HIF-1 $\alpha$ protein accumulation. In cell culture models, it has been shown that in the early phase of hypoxia (the first $2 \mathrm{~h}$ ), the level of NO concentration increases and leads to inhibition of prolyl hydroxylases and HIF-1 $\alpha$ accumulation. In the late phase (after $2 \mathrm{~h}$ ), however, as the levels of newly synthesized prolyl hydroxylases increase, an antagonistic effect of hypoxia and $\mathrm{NO}$ on HIF-1 $\alpha$ stabilization occurs (Berchner-Pfannschmidt et al. 2007). 

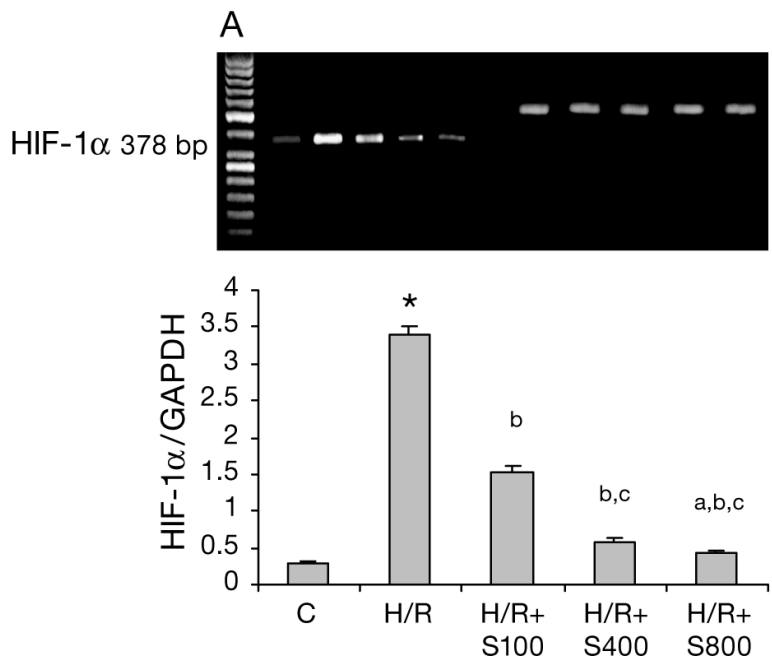

C
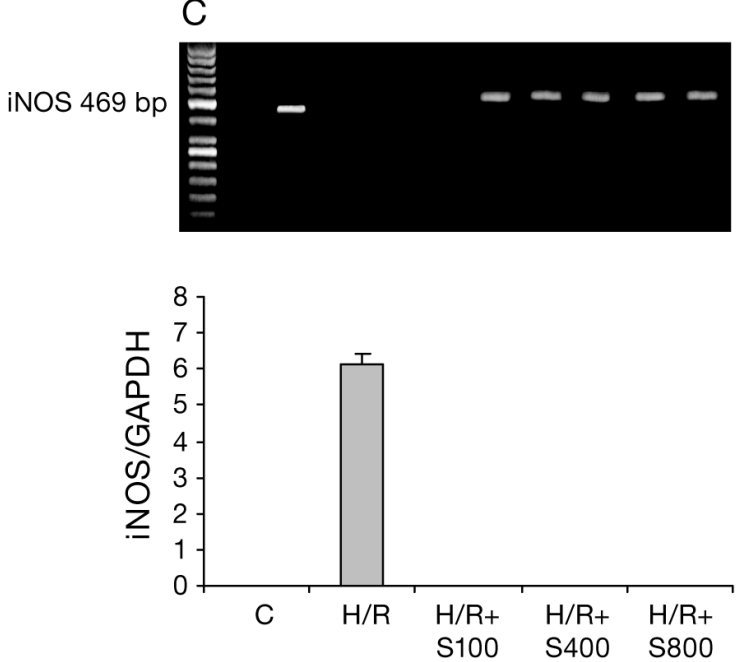

$\mathrm{B}$
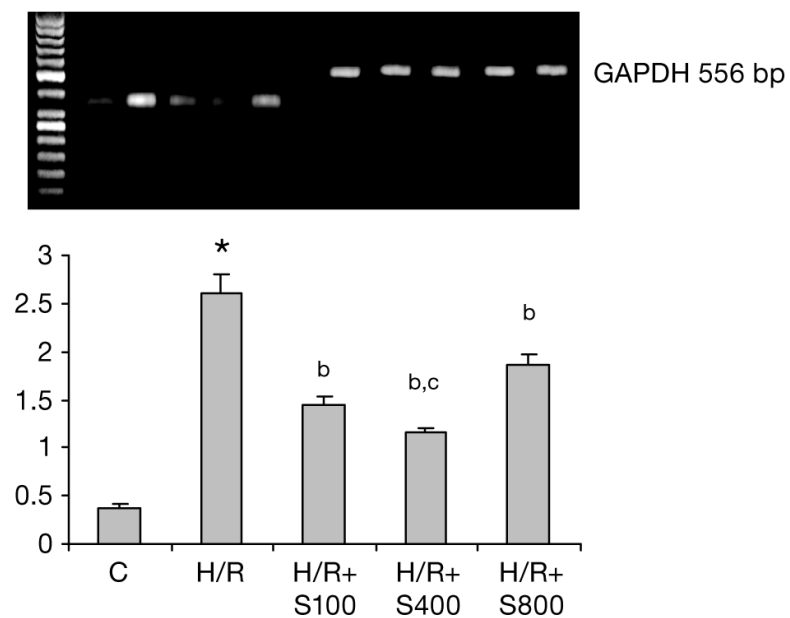

D

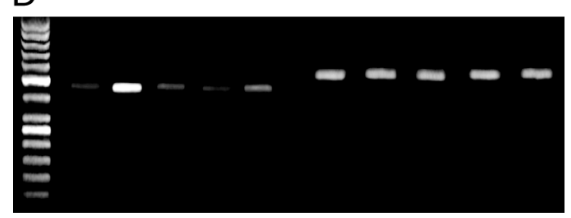

GAPDH 556 bp

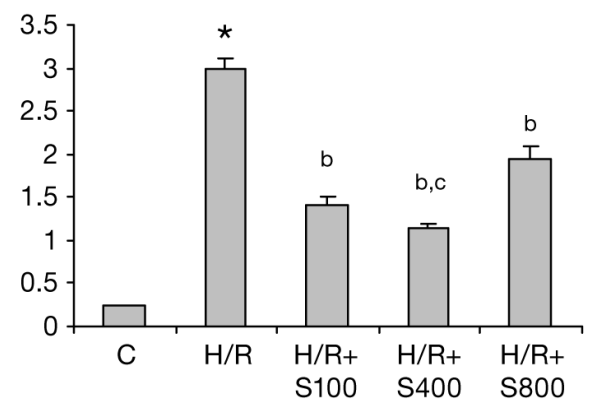

Fig. 4. Oncorhynchus mykiss. Effect of SMN on (A) HIF-1 $\alpha$ expression in the brain, (B) HIF-1 $\alpha$ expression in the gills, (C) iNOS expression in the brain and (D) iNOS expression in the gills; upper panels: expressed level of both genes along with the corresponding GAPDH gene in the brain and gills on an agarose gel; lower panel: mRNA levels of either gene normalized to the GAPDH mRNA expression level from corresponding animals. Results were expressed as integrated density values (IDV) of HIF- $1 \alpha$ and iNOS mRNA levels. C: control; H/R: trout exposed to $3 \mathrm{~h}$ hypoxia followed by $3 \mathrm{~h}$ reoxygenation; H/R+S100, +S400, +S800: trout pretreated with 100, 400, $800 \mathrm{mg} \mathrm{kg}^{-1}$ SMN before H/R, respectively. ${ }^{*}$ Significant $(\mathrm{p}<0.01)$ difference between the control and H/R groups. Different lowercase letters represent significant differences between the H/R and SMN-treated groups and among the SMN-treated groups themselves

Our data showed a clear up-regulation of iNOS in the examined organs after the H/R period. As in hypoxic situations, both genes were up-regulated; therefore, it may be concluded that another important factor in hypoxia and the HIF-1 $\alpha$ and NO concentration complex should be iNOS. In H/R-exposed trout, following an up-regulation of HIF-1 $\alpha$ and iNOS, the iNOS-derived NO level is elevated and in turn leads to sustained HIF-1 $\alpha$ levels. The key role of iNOS-derived NO levels in the regulation of HIF-1 $\alpha$ has been reported in microvascular endothelial cells (Natarajan et al. 2005). Moreover, up-regulation of
iNOS after $30 \mathrm{~min}$ of hypoxia followed by $2 \mathrm{~h}$ of reoxygenation in rat lungs has also been demonstrated (Rus et al. 2010).

Another interesting finding of the present study is that $3 \mathrm{~d}$ of pretreatment with SMN before the H/R treatment resulted in a remarkable protective effect both on H/R-induced biochemical changes and on the expression of HIF-1 $\alpha$ and iNOS in the examined tissues.

Antioxidant effects of SMN in various forms, such as reducing the lipid peroxidation in the brain of rats (Galhardi et al. 2009), reversing the sepsis-decreased 
tissue glutathione and total antioxidant capacity in the lungs and brain of rats (Toklu et al. 2008), enhancing the acetaminophen-reduced superoxide dismutase activity and ascorbic acid level in the brain of rats (Nencini et al. 2007) and lowering the lipopolysaccharide-induced nitrite in mesencephalic mixed neuron-glia cultures, have been shown (Wang et al. 2002). However, there is scarce data to show the antioxidant effect of SMN in aquatic animals. Therefore, our findings extended the knowledge of the antioxidant properties of SMN in trout for protection from H/R-induced oxidative damages. Previous studies reported that SMN treatments resulted in a significant suppression of iNOS expression in the liver, kidney and heart of pyridine-exposed Syrian hamsters (Tunca et al. 2009). Therefore, SMN acts both transcriptionally and post-transcriptionally, as we showed in the present study. The antioxidant effect of SMN is mainly attributable to its antiradical and ROS scavenging capabilities (Kiruthiga et al. 2007, Shaker et al. 2010). Moreover, other mechanisms, such as increasing the pro-oxidant-reduced mitochondrial membrane potential and inhibition of the sepsis-elevated cytokines (IL-1 $\beta$ and PGE $_{2}$ ) production, can also explain the SMN-induced antioxidant effects (Kang et al. 2004).

Although the protective effects of SMN on the brain were dose dependent, the TAC and all measured oxidative/nitrosative markers in the gills at the highest given dose of SMN did not follow the dosedependency. The pro-oxidant effect of flavonoids at high concentrations, as reported in the present study, may be related to auto-oxidation and increased ROS generation. The cytotoxic effect of baicalein as a known antioxidant flavonoid at higher doses on cardiomyocytes has been demonstrated (Woo et al. 2005). The obtained pro-oxidant properties of SMN at the highest given dose, which were characterized by a significant increase of NO and MDA levels in the gills of trout, may be explained by various dosedependent effects of SMN. SMN exerted various effects in different organs at the highest given dose levels. Although there are no available data regarding the pharmacokinetics of SMN in trout, these different effects may be associated with differing amounts of distributed SMN into specific organs. Pharmacokinetic analyses in mice indicated different amounts of recovered silibinin, an active compound of SMN, following oral administration in different organs of mice, supporting our hypothesis of uneven distribution (Zhao \& Agarwal 1999).

Our histopathological findings in the brain support the biochemical and molecular findings. The cere- bral edema observed in the H/R group may be related to vascular injuries and released vasoactive metabolites, such as arachidonic acid and lactic acids (Grace 1994). Thus, in aquatic animals, including trout, both hypoxia and reoxygenation may result in cerebral injuries, as are reported in the current study. A possible explanation for the increase of free radicals and NO content of the H/R-treated brain may be a massive influx of $\mathrm{Ca}^{2+}$ and activation of NO synthesis, which may occur after H/R-induced damage to cell membranes (Gilgun-Sherki et al. 2002). Interestingly, the SMN pretreatment resulted in the same kind of protective effects that we observed in the biochemical and molecular analyses, and the appropriate pretreatment concentration for the H/R-induced damages in the gills is lower (400 $\mathrm{mg} \mathrm{kg}^{-1}$ feed) than that needed for the brain injuries ( $800 \mathrm{mg} \mathrm{kg}^{-1}$ feed). The reason for this diversity may relate to the concentrations of SMN that reach the proposed tissue. Because in principle SMN does not dissolve in water, its major absorption via the gill surfaces cannot be the reason for the obtained pathological damages in the gills. Our careful daily surveillance showed no reduction in food intake, suggesting that even at high doses of SMN, the fish feed did not become unpalatable. Therefore, the high concentration of SMN should be provided to the gills mainly via systemic blood circulation, which may consequently result in a pro-oxidant effect.

In conclusion, we report for the first time the protective effects of SMN on H/R-induced biochemical, histopathological and transcriptional alterations in trout. The protective effect of SMN may be explained by its antioxidant properties, which reflect its capability to reduce the H/R-elevated NO concentration, MDA formation and protein oxidation. SMN might regulate HIF-1 $\alpha$ expression through iNOS-derived NO concentrations. These findings could be applicable in future pharmacokinetics studies and may help to reduce H/R-induced damages in trout.

Acknowledgements. We are grateful to Dr. M. Razi from the histology department of Urmia University for his valuable assistance in editing the photomicrographs.

\section{LITERATURE CITED}

Aprelikova O, Chandramouli GVR, Wood M, and others (2004) Regulation of HIF prolyl hydroxylases by hypoxiainducible factors. J Cell Biochem 92:491-501

Beckman JS, Beckman TW, Chen J, and others (1990) Apparent hydroxyl radical production by peroxynitrite: implications for endothelial injury from nitric oxide and superoxide. Proc Natl Acad Sci USA 87:1620-1624 
Benzie IF, Strain JJ (1999) Ferric reducing/antioxidant power assay: direct measure of total antioxidant activity of biological fluids and modified version for simultaneous measurement of total antioxidant power and ascorbic acid concentration. Methods Enzymol 299:15-27

Berchner-Pfannschmidt U, Yamac H, Trinidad B, and others (2007) Nitric oxide modulates oxygen sensing by hypoxia-inducible factor 1-dependent induction of prolyl hydroxylase 2. J Biol Chem 282:1788-1796

Brown GC (1999) Nitric oxide and mitochondrial respiration. Biochim Biophys Acta 1411:351-369

> Chomczynski P, Sacchi N (2006) The single-step method of RNA isolation by acid guanidinium thiocyanate-phenolchloroform extraction: twenty-something years on. Nat Protoc 1:581-585

Chuanyu L, Jackson R (2002) Reactive species mechanisms of cellular hypoxia-reoxygenation injury. Am J Physiol Cell Physiol 282:227-241

Collet B, Hovens GC, Mazzoni D, and others (2003) Cloning and expression analysis of rainbow trout Oncorhynchus mykiss interferon regulatory factor 1 and 2 (IRF-1 and IRF-2). Dev Comp Immunol 27:111-126

> Coolidge EH, Ciuhandu CS, Milsom WK (2008) A comparative analysis of putative oxygen-sensing cells in the fish gill. J Exp Biol 211:1231-1242

Curtin JF, Donovan M, Cotter TG (2002) Regulation and measurement of oxidative stress in apoptosis. J Immunol Methods 265:49-72

Dröge W (2002) Free radicals in the physiological control of cell function. Physiol Rev 82:47-95

Filho DW, Torres MA, Zaniboni-Filho E, and others (2005) Effect of different oxygen tensions on weight gain, feed conversion, and antioxidant status in piapara, Leporinus elongatus (Valenciennes, 1847). Aquaculture 244:349-357

Galhardi F, Mesquita K, Monserrat JM, and others (2009) Effect of silymarin on biochemical parameters of oxidative stress in aged and young rat brain. Food Chem Toxicol 47:2655-2660

Gilgun-Sherki Y, Rosenbaum Z, Melamed E, and others (2002) Antioxidant therapy in acute central nervous system injury: current state. Pharmacol Rev 54:271-284

Grace PA (1994) Ischaemia-reperfusion injury. Br J Surg 81: 637-647

Green LC, Wagner DA, Glogowski J, and others (1982) Analysis of nitrate, nitrite, and $\left[{ }^{15} \mathrm{~N}\right]$ nitrate in biological fluids. Anal Biochem 126:131-138

Ivan M, Kondo K, Yang HF, and others (2001) HIF $\alpha$ targeted for VHL-mediated destruction by proline hydroxylation: implications for $\mathrm{O}_{2}$ sensing. Science 292:464-468

Kang JS, Jeon YJ, Park SK, and others (2004) Protection against lipopolysaccharide-induced sepsis and inhibition of interleukin-1 $\beta$ and prostaglandin E2 synthesis by silymarin. Biochem Pharmacol 67:175-181

Kiruthiga PV, Shafreen RB, Pandian SK, and others (2007) Silymarin protection against major reactive oxygen species released by environmental toxins: exogenous $\mathrm{H}_{2} \mathrm{O}_{2}$ exposure in erythrocytes. Basic Clin Pharmacol Toxicol 100:414-419

Kitazoe Y, Kishino H, Hasegawa M, and others (2011) Stability of mitochondrial membrane proteins in terrestrial vertebrates predicts aerobic capacity and longevity. Genome Biol Evol 3:1233-1244

Levine RL, Williams JA, Stadtman ER, and others (1994) Carbonyl assays for determination of oxidatively modified proteins. Methods Enzymol 233:346-357
Li ZH, Zlabek V, Velisek J, and others (2011) Acute toxicity of carbamazepine to juvenile rainbow trout (Oncorhynchus mykiss): effects on antioxidant responses, hematological parameters and hepatic EROD. Ecotoxicol Environ Saf 74:319-327

Lowry OH, Rosebrough NJ, Farr AL, and others (1951) Protein measurement with the Folin phenol reagent. J Biol Chem 193:265-275

> Lundgreen K, Kiilerich P, Tipsmark CK, and others (2008) Physiological response in the European flounder (Platichthys flesus) to variable salinity and oxygen conditions. J Comp Physiol B 178:909-915

Lushchak VI, Bagnyukova TV (2006a) Temperature increase results in oxidative stress in goldfish tissues: 1 . Indices of oxidative stress. Comp Biochem Physiol C 143:30-35

Lushchak VI, Bagnyukova TV (2006b) Temperature increase results in oxidative stress in goldfish tissues: 2. Antioxidant and associated enzymes. Comp Biochem Physiol C 143:36-41

Lushchak VI, Bagnyukova TV (2007) Hypoxia induces oxidative stress in tissues of a goby, the rotan Perccottus glenii. Comp Biochem Physiol B 148:390-397

McKenzie DJ, Wong S, Randall DJ, and others (2004) The effects of sustained exercise and hypoxia upon oxygen tensions in the red muscle of rainbow trout. J Exp Biol 207:3629-3637

Meeran SM, Katiyar S, Elmets CA, Katiyar SK (2006) Silymarin inhibits UV radiation-induced immunosuppression through augmentation of interleukin-12 in mice. Mol Cancer Ther 5:1660-1668

Natarajan R, Jones DG, Fisher BJ, and others (2005) Hypoxia inducible factor-1: regulation by nitric oxide in posthypoxic microvascular endothelium. Biochem Cell Biol 83:597-607

Nencini C, Giorgi G, Micheli L (2007) Protective effect of silymarin on oxidative stress in rat brain. Phytomedicine 14:129-135

> Niehaus WG Jr, Samuelsson B (1968) Formation of malonaldehyde from phospholipid arachidonate during microsomal lipid peroxidation. Eur J Biochem 6:126-130

> Nikinmaa M, Rees BB (2005) Oxygen-dependent gene expression in fishes. Am J Physiol Regul Integr Comp Physiol 288:R1079-R1090

Nilsson GE, Renshaw GMC (2004) Hypoxic survival strategies in two fishes: extreme anoxia tolerance in the North European crucian carp and natural hypoxic preconditioning in a coral-reef shark. J Exp Biol 207:3131-3139

> Olson KR (2008) Hydrogen sulfide and oxygen sensing: implications in cardiorespiratory control. J Exp Biol 211: 2727-2734

Palmer LA, Semenza GL, Stole MH, and others (1998) Hypoxia induces type II NOS gene expression in pulmonary artery endothelial cells via HIF-1. Am J Physiol Lung Cell Mol Physiol 18:212-219

Piper RG, McElwain IB, Orme LE, and others (1982) Fish hatchery management. US Dep of the Interior, Fish and Wildlife Service, Washington, DC

> Rissanen E, Tranberg HK, Nikinmaa M (2006) Oxygen availability regulates metabolism and gene expression in trout hepatocyte cultures. Am J Physiol Regul Integr Comp Physiol 291:R1507-R1515

> Rus A, Peinado MA, Castro L, and others (2010) Lung eNOS and iNOS are reoxygenation time-dependent upregulated after acute hypoxia. Anat Rec 293:1089-1098

> Shaker E, Mahmoud H, Mnaa S (2010) Silymarin, the anti- 
oxidant component and Silybum marianum extracts prevent liver damage. Food Chem Toxicol 48:803-806

Stroka DM, Burkhardt T, Desbaillets I, and others (2001) HIF-1 is expressed in normoxic tissue and displays an organ-specific regulation under systemic hypoxia. FASEB J 15:2445-2453

Toklu HZ, Tunali-Akbay T, Velioglu-Ogunc A, and others (2008) Silymarin, the antioxidant component of Silybum marianum, prevents sepsis-induced acute lung and brain injury. J Surg Res 145:214-222

Tunca R, Sozmen M, Citil M, and others (2009) Pyridine induction of cytochrome P450 1A1, iNOS and metallothionein in Syrian hamsters and protective effects of silymarin. Exp Toxicol Pathol 61:243-255

> Valko M, Leibfritz D, Moncol J, and others (2007) Free radicals and antioxidants in normal physiological functions and human disease. Int J Biochem Cell Biol 39:44-84

Wang T, Ward M, Grabowski P, and others (2001) Molecular

Editorial responsibility: Helmut Segner,

Bern, Switzerland cloning, gene organization and expression of rainbow trout (Oncorhynchus mykiss) inducible nitric oxide synthase (iNOS) gene. Biochem J 358:747-755

Wang MJ, Lin WW, Chen YH, and others (2002) Silymarin protects dopaminergic neurons against lipopolysaccharide-induced neurotoxicity by inhibiting microglia activation. Eur J Neurosci 16:2103-2112

Woo AY, Cheng CH, Waye MM (2005) Baicalein protects rat cardiomyocytes from hypoxia/reoxygenation damage via a prooxidant mechanism. Cardiovasc Res 65:244-253

Zhang H, Mu Z, Xu LM, and others (2009) Dietary lipid level induced antioxidant response in manchurian trout, Brachymystax lenok (Pallas) larvae. Lipids 44:643-654

Zhao J, Agarwal R (1999) Tissue distribution of silibinin, the major active constituent of silymarin, in mice and its association with enhancement of phase II enzymes: implications in cancer chemoprevention. Carcinogenesis 20:2101-2108

Submitted: December 22, 2011; Accepted: March 5, 2012 Proofs received from author(s): May 14, 2012 